\title{
Reading Aid: 2 Maccabees and the History of Jason of Cyrene Reconsidered
}

\author{
Francis Borchardt \\ 50 Tao Fung Shan Road, Shatin, Hong Kong \\ Lutheran Theological Seminary Hong Kong \\ archaeology@gmail.com
}

\begin{abstract}
This article investigates the prefatory material in 2 Maccabees (2:19-32; 15:38-39) in order to reveal the motivation and attitude of the epitomator of 2 Maccabees toward the text he is adapting. The article argues that the concept of auxiliary texts, recognized in Graeco-Roman and Hellenistic texts by classicist Markus Dubischar, is the lens through which to properly understand the preface and therefore the scribe's motivation for textual adaptation. The article further employs these conclusions to question whether other texts from the Judean milieu might also be best understood in this category.
\end{abstract}

Keywords

2 Maccabees - scribal practice - preface - text criticism

\section{Introduction}

Advances have recently been made by biblical scholars wishing to understand better the processes by which ancient texts were produced and

* The author is grateful to Martti Nissinen, Juha Pakkala, and all the members of the Academy of Finland Center of Excellence at the University of Helsinki Faculty of Theology. Their financial support and critical remarks on an earlier form of this paper have been helpful in bringing the project to completion. 
transmitted. ${ }^{1}$ The main impetus for such studies, and the reason for their facility is almost certainly the publication and edition of the texts found in the Judean desert. ${ }^{2}$ These most ancient copies of texts later included among Jewish and Christian canons, alongside many other fascinating examples, have turned the discussion of the production and transmission of sacred and/or authoritative literature upon its head.

Because many texts, from parts of the Pentateuch to the Rule of the Community, appear in multiple forms side by side it is probably no longer possible to think of linear processes of textual development proceeding from Urtext to "final form" with well-defined stages of growth along the way. ${ }^{3}$ Instead, based on the evidence of Jubilees, the Temple Scroll (11QT ${ }^{\mathrm{a}}$ ), 4QReworked Pentateuch (4Q158, 364-367), and other versions of the pentateuchal tradition (e.g., 4Q422, 1 QapGen), texts appear to have been transmitted fluidly and in a variety of different forms and genres, as Eugene Ulrich, Sidnie White Crawford, and many others have argued. ${ }^{4}$ This realization is made possible by the existence of texts

1 See, e.g., Hanne von Weissenberg, Juha Pakkala, and Marko Marttila, "Introducing Changes in Scripture," in Changes in Scripture: Rewriting and Interpreting Authoritative Traditions in the Second Temple Period (ed. Hanne von Weissenberg, Juha Pakkala, and Marko Marttila; Berlin: de Gruyter, 2011), 3-20, esp. 4; Eugene Ulrich, The Dead Sea Scrolls and the Origins of the Bible (Grand Rapids: Eerdmans, 1999), 18; and Molly Zahn, Rethinking Rewritten Scripture: Composition and Exegesis in the 4QReworked Pentateuch Manuscripts (Leiden: Brill, 2011), 1.

2 Ronald Hendel, "Assessing the Text-Critical Theories of the Hebrew Bible after Qumran," in The Oxford Handbook of the Dead Sea Scrolls (ed. Timothy Lim and John Collins; Oxford: Oxford University Press, 2010), 281-302, esp. 281-82: "Hence, the discovery of the Qumran biblical texts entails not only the existence of new evidence, but a rediscovery of the importance of the textual evidence that we already had."

3 On the diminishment of the Urtext see Eugene Ulrich, "The Evolutionary Production and Transmission of the Scriptural Books," in von Weissenberg, Pakkala, and Marttila, Changes in Scripture, 47-64, esp. 49; Hans Debel, "Greek 'Variant Literary Editions' to the Hebrew Bible?" JSJ 41 (2010): 161-90, esp. 163-73. On the multiple forms of the Rule of the Community see specifically Sarianna Metso, The Textual Development of the Qumran Community Rule (Leiden: Brill, 1997) and Alison Schofield, From Qumran to the Yahad: A New Paradigm of Textual Development for The Community Rule (Leiden: Brill, 2009). On the pluriform nature of the pentateuchal tradition Emanuel Tov, Textual Criticism of the Hebrew Bible (2nd rev. ed.; Minneapolis: Augsburg Fortress, 2001).

4 Sidnie Crawford, Rewriting Scripture in Second Temple Times, (Grand Rapids: Eerdmans, 2008), esp. 327-32, argues for a continuum of transmission with one end of the spectrum occupied by word-for-word copying, and the other end occupied by commentaries. See also George Brooke, "The Rewritten Law, Prophets, and Psalms: Issues for Understanding the Text of the Bible," in The Bible as Book: The Hebrew Bible and the Judean Desert Discoveries (ed. Edward Herbert and Emanuel Tov; London: British Library, 2002), 31-40; James VanderKam, 
displaying the variety of transmission techniques and the sometimes wildly divergent works which these techniques have produced. ${ }^{5}$ The value of such finds is that the reality of purposeful and free textual change can no longer be assigned to second rate copyists, or neglected as a peculiarity of the Old Greek transmission process.

This type of evidence has led to a new emphasis on empirical examples of the methods of textual transmission in fields other than Dead Sea Scrolls scholarship. One reason for this is that the finds from Qumran validated the antiquity of many of the readings found in the Samaritan Pentateuch and Old Greek transmissions of texts previously thought to be divergent. ${ }^{6}$ This means that textual criticism focusing on the Greek text or the Samaritan tradition is no longer an unfavored sub-field of biblical studies, but a source for recovering ancient examples of the types of variation for which literary critics have long argued. ${ }^{7}$

Beyond this, many scholars have recognized the value of an even broader range of manuscripts and textual witnesses. Liv Lied, for instance, has been employing the methods of book historians of the medieval period, termed the new philology, to advocate the importance of the physical appearance and material context of individual manuscripts alongside textual concerns in order to better understand the function, status, and techniques of transmission into

"Questions of Canon Viewed Through the Dead Sea Scrolls," BBR 11 (2001): 269-92, esp. 280, 292 , also presents these texts as existing on a continuum. See, however, the critical remarks of Zahn, Rethinking, 239-41.

5 Many fine studies have traced the techniques used by ancient scribes in transmitting various traditions found at Qumran. Notable examples include Michael Segal, "Biblical Exegesis in 4Q158: Techniques and Genre," Textus 19 (1998): 45-62; Moshe Bernstein, "What Has Happened to the Laws? The Treatment of Legal Material in 4QReworked Pentateuch," DSD 15 (2008): 24-49; Molly Zahn, "The Problem of Characterizing the 4QReworked Pentateuch Manuscripts: Bible, Rewritten Bible, or None of the Above?" DSD 15 (2008): 31539; Crawford, Rewriting, particularly in chapters 2-7.

6 Tessa Rajak, Translation and Survival: The Greek Bible of the Ancient Jewish Diaspora (Oxford: Oxford University Press, 2009), 19 notes: "Thus, an even more intricate task within the domain of textual criticism is the exploitation of the Greek as a route to our understanding of the development of the Hebrew text. The Qumran material has of course transformed what was once a desultory activity into an all-absorbing investigation." Ulrich, Dead Sea Scrolls, 225, adds: "Some of the texts that show [pluriformity in the text tradition], principally the Samaritan Pentateuch (SP) and the Old Greek (OG), lay within easy reach of scholars through the centuries but were not generally understood in this context. However, the scrolls from Qumran and other sites along the Dead Sea paint the picture with exciting clarity."

7 Crawford, Rewriting, 58-61. 
late antiquity and the middle ages. ${ }^{8}$ These ideas have led her to emphasize the contextuality of variance, seriously questioning scholars who, despite recognizing fluidity, would still seek particular stages of textual growth beyond the material evidence. ${ }^{9}$ Since variance is a central part of manuscript culture, Lied calls for focusing on the (often) medieval manuscripts we have within their cultural context both as the starting point and goal of research. ${ }^{10}$

Others, such as Karel van der Toorn and David Carr have recognized the importance of orality and tradition in ancient scribal culture and education, particularly in the Ancient Near East and Mediterranean and on this basis have argued that much textual change might be the result of memorization alongside a recognized freedom in scribal performance. ${ }^{11}$ These studies are perhaps more theoretical in nature, since oral transmission cannot be observed firsthand in the ancient context, and scribal education in Judea remains largely an enigma. However, the empirical examples from within the Bible and nearby literary cultures offer firm examples upon which hypotheses might be built. ${ }^{2}$

This renewed emphasis on empirical evidence of text production, transmission, and reception (phenomena which can no longer be neatly divided) is welcome. ${ }^{13}$ The concentration upon irrefutable examples of ongoing adaptation forces scholars to recognize that the so-called final form of the text with which they work is a relatively modern artifact, and encourages a reexamination of hypotheses that proceed from such late and artificial forms of the texts with which we work as though they are representative of the mind of a particular ancient scribe and/or community. ${ }^{14}$ Further, the focus on empirical

8 Liv Lied, "Media Culture, New Philology, and the Pseudepigrapha," n.p. [cited 25 June, 2014] Online: https://www.academia.edu/4131828/Lied._Media_Culture_New_Philology_ and_the_Pseudepigrapha._SBL_2012, 2.

9 Ibid., 2.

$10 \quad$ Ibid., 3-4; Lied, "Textual Transmission and Liturgical Transformation of 2 Baruch in Syriac Monasticism," n.p. [cited 25 June, 2014] Online: https://www.academia.edu/4227179/ Paper._Transmission_and_Transformation_of_2_Baruch._Challenges_to_Editors._The Rest_is_Commentary_Yale_28_April_2013, 2.

Karel van der Toorn, Scribal Culture and the Making of the Hebrew Bible (Cambridge: Harvard University Press, 2007), particularly chapters 1, 2, and 5, but such insights are found throughout the book; David Carr, Writing on the Tablet of the Heart: Origins of Scripture and Literature (Oxford: Oxford University Press, 2005), 4-5.

12 Van der Toorn, Scribal, 2, 75.

13 Ulrich, "Evolutionary," 49.

14 It is now even commonplace for scholars to claim that authors, as such, do not exist in ancient Near Eastern literary culture, preferring instead scribes. See William Schniedewind, How the Bible Became a Book: The Textualization of Ancient Israel (Cambridge: Cambridge 
evidence at times corrects and at other times supports the more theoretical conclusions traditio-historical criticism has reached over the past century and a half. It thus sharpens our knowledge as historians of the process of production, even as it obfuscates much of our understanding of the circumstances in which any given variant reading might have been produced. ${ }^{15}$

\section{Aims}

While it is often easy to demonstrate technique and results from the empirical evidence for textual variance, motivation and scribal attitudes toward the text remain in the realm of theory. ${ }^{16}$ The theory, when employed correctly, might be reflected in the techniques, but given the fluid nature of texts and traditions, it is not suited to the task of determining why one specific manuscript or text-form differs from another. There has been little reflection on this oversight to date. Effect is not equal to intent. Nor, for that matter, is technique, as Molly Zahn has shown in her dissertation, Rethinking Rewritten Scripture. ${ }^{17}$ It is also problematic to determine how such changes to texts and traditions were received, and whether they were even detectable to the listening and reading audiences. This leaves a lacuna in our knowledge concerning the process of transmission which is difficult to fill.

University Press, 2004), 7; and van der Toorn, Scribal, 27-50. See, however, the criticisms of this too-narrow view of authorship by John Van Seters, "The Origins of the Hebrew Bible: Some New Answers to Old Questions," JANER 7 (2007): 87-108, esp. 89-91.

15 Eugene Ulrich, "From Literature to Scripture: Reflections on the Growth of a Text's Authoritativeness," DSD 10 (2003): 3-25, esp. 5, notes that texts grew and were passed on dynamically for centuries "through the repeated creativity of anonymous religious leaders and thinkers, priests and scribes." The quote illustrates just how difficult it would be to pinpoint the source for any given change. Ulrich, "Evolutionary," 53, elsewhere notes that the hypothetical demonstrations of literary-critical analyses were proven by the texts at Qumran.

16 E.g. Ulrich, "Evolutionary," 57-6o, outlines a number of the effects variations on certain traditions have as a means to describe motive, but does not produce evidence for the intent of the scribe who produced such a variation. Van der Toorn, Scribal, too, whenever he discusses motives, offers conjectures based upon general observations concerning the changing eras or locations in which texts were read.

17 Zahn, Rethinking, 233-35, speaks specifically of additions of new material, minor alterations, and paraphrases in this vein. However, even the more determined types of changes, such as additions of material from elsewhere and rearrangement of a text's sequence are used in a variety of ways according to her observations. 
I would like to propose a possibility for how to fill this gap in our knowledge concerning the motivations of changes made in texts and traditions: Why not ask the scribes themselves? Obviously it is not possible to interview the ancient scribes responsible for creating and passing on the texts in our purview. Unless readers have access to a trustworthy medium who can conjure the dead, we shall probably need to abandon that method. That being expressed, some ancient scribes did leave hints concerning their attitudes toward texts and the changes made to them in the form of proems, prologues, and colophons, all of which are included by literary critic Gérard Genette under the category of prefatory writings. ${ }^{18}$ These often reveal not only the identity of the author and/or work, but also the scribe's reason for producing a written work and their attitude toward a given text. ${ }^{19}$ We primarily find such prefatory writings in Graeco-Roman texts from antiquity, but a few examples can be found in the literature of the Ancient Near East, and in Judean texts of the Hellenistic era. ${ }^{20}$

One such prologue, upon which we shall focus here is 2 Macc 2:19-32, and its epilogue in 15:38-39. This text is especially interesting because it not only contains a prefatory writing, but the preface is evidently written by an author responsible for changing an earlier text (2 Macc 2:23, 26, 30-32). As opposed to tradents like the ostensible descendant of Ben Sira who seems to apologize for the changes introduced by the Greek translation of his ancestor's work (Prologue 20-26), and Josephus, in his prologue to the Judean Antiquities (1.17), who denies any change, ${ }^{21}$ the tradent responsible for 2 Maccabees makes no

18 Gérard Genette, Paratexts: Thresholds of Interpretation (trans. Jane Lewin; Cambridge: Cambridge University Press, 1997), 161.

19 Markus Dubischar, "Survival of the Most Condensed? Auxiliary Texts, Communications Theory, and Condensation of Knowledge," in Condensing Texts-Condensed Texts (ed. Marietta Horster and Christiane Reitz; Stuttgart: Steiner, 2010), 39-68, esp. 44-47. Dubischar, "Survival," 44-47, provides a list of the prefatory writings in GraecoRoman "auxiliary" texts, a count of which comes to 29. Loveday Alexander, The Preface to Luke's Gospel: Literary Convention and Social Context in Luke 1.1-4 and Acts 1.1 (Cambridge: Cambridge University Press, 1993), 147-67, highlights several of the Judean prefaces and their particular features.

21 On the various interpretations of Josephus's claim not to have added or omitted anything from his review of the contents of his scriptures and their context in Graeco-Roman and Judean literary milieux see primarily Sabrina Inowlocki, “Neither Adding or Omitting Anything': Josephus's Promise not to Modify the Scriptures in the Greek and Latin Context," JJS 46 (2005): 48-65; Armin Lange, "'Nobody Dared to Add to Them, to Take from Them, or to Make Changes' (Josephus, Ag. Ap. 1.42): The Textual Standardization of Jewish Scriptures in Light of the Dead Sea Scrolls," in Flores Florentino: Dead Sea Scrolls 
effort to apologize for or hide his own contributions in the process of transmission and transformation of the text he receives. Instead, he advertises that he is epitomizing or abridging the text, a claim which has earned him the title "epitomator" among scholars. ${ }^{22}$ I hope to show that, on account of this oddity, this text reveals valuable information regarding the attitude toward changed texts and motivations for change in Judean antiquity. ${ }^{23}$ Further, I will show that it should be taken as important evidence when considering the reasons any given scribe might have made changes to a text the scribe transmits. Though this evidence certainly cannot be made to represent the point of view of all Judean scribes of the Hellenistic or any other period, it should be taken seriously as a text that reveals part of the horizon of expectations available to the scribe and early audiences. ${ }^{24}$ This is of special importance precisely because the relationship between scribes, texts, and audiences has often been based on anachronistic constructs of each of these participants in ancient literary culture. ${ }^{25}$

There are, of course, obvious objections that might be raised regarding whether a successful proof of my thesis could be applied to other texts within the Judean literary milieu. Most important among these are the evident differences between the book culture of much of Graeco-Roman and Hellenistic periods, especially among Greeks and Romans, and the scribal culture of the Ancient Near East. These differences manifest themselves in the existence of a

and Other Early Jewish Studies in Honour of Florentino García Martínez (ed. Anthony Hilhorst, Émile Puech, and Eibert Tigchelaar; Leiden: Brill, 2007), 105-26; Louis Feldman, Josephus' Interpretation of the Bible (Berkeley: University of California Press, 1998), 37-46; Jonathan Campbell, "Josephus' Twenty-Two Book Canon and the Qumran Scrolls," in The Scrolls and Biblical Traditions: Proceedings of the Seventh Meeting of the IOQs in Helsinki (ed. George Brooke et al.; Leiden: Brill, 2012), 19-45.

22 See, e.g., Daniel Schwartz, 2 Maccabees (Berlin: de Gruyter, 2008), 28, who goes on to reject the term in favor of "author" (p. 37).

23 Judean is here used in the sense of Steve Mason, "Jews, Judeans, Judaizing, Judaism: Problems of Categorization in Ancient History," JSJ 38 (2007): 457-512. I make no claims to either Jason of Cyrene or the epitomator having produced their works in Judea. Indeed, it would seem that the preponderance of evidence is against such a conclusion. See Schwartz, 2 Maccabees, 55 .

24 Hans Jauss, Toward an Aesthetic of Reception (trans. Timothy Bahtu; Minneapolis: University of Minnesota Press, 1982), 22, coins this term to describe the ideas and institutions present in a given historical circumstance.

25 The situation has improved in recent decades with many scholars taking note of the difference in context (see, e.g., Philip Davies, Scribes and Schools: The Canonization of the Hebrew Scriptures [Louisville: Westminster John Knox, 1998], 16), but the low quality of evidence continues to pose a problem. 
book trade, libraries, authorship, and titled works. ${ }^{26}$ Few of these institutions can be demonstrated broadly in the Judean environment. Further, though texts certainly were attributed with something that might be considered authority, and could be thought of as belonging to an educational canon in the GraecoRoman and Hellenistic world, the type of scriptural use and reliance on texts observed in Judean circles is largely absent in the Greek and Roman world. ${ }^{27}$ Though these may seem like formidable obstacles to the use of such examples beyond the several Judean works with prefatory writings, or at least authors, a few points suggest broader applicability. First, the convention of assigning commonly-understood titles to written books is not nearly as widespread in the Graeco-Roman milieu as one would imagine. It is very often difficult to find what specific writing is being referenced or quoted in ancient fragments and collected works. ${ }^{28}$ Second, though we know some texts did reach authoritative and even scriptural status at some point for many Judeans, it is both difficult to determine at what point this occurred, and even harder to determine whether this status had any effect on the actual form of the text. ${ }^{29}$ Third, nearly all of our empirical evidence for the transmission of Judean texts in various forms, whether the Dead Sea scrolls, the Septuagint, or the Samaritan

26 On these subjects see van der Toorn, Scribal, 9, who claims that books do not exist in the Mediterranean or Near East until well into the Hellenistic period. Armin Lange, "In the Second Degree: Ancient Jewish Paratextual Literature in the Context of Graeco-Roman and Ancient Near Eastern Literature," in In the Second Degree: Paratextual Literature in Ancient Near Eastern and Ancient Mediterranean Culture and its Reflections in Medieval Literature (ed. Philip Alexander, Armin Lange, and Renate Pillinger; Leiden: Brill, 2010), 3-42, esp. 6-7, largely agrees. He notes that the Greeks may have had the concepts of books and authors already in the 6 th and $5^{\text {th }}$ centuries BCE, but that these conventions are largely foreign in the Judean milieu until a later period, and even then are rare. Leighton Reynolds and N. G. Wilson, Scribes and Scholars: A Guide to the Transmission of Greek and Latin Literature (3rd ed.; Oxford: Clarendon, 1991), 1-43, add further nuance in describing the advent of book culture in the classical period, with a true realization of books and book culture only in the libraries and book trade of the hellenistic period.

27 The educational canon and its contents are discussed extensively in Raffaella Cribiore, Gymnastics of the Mind: Greek Education in Hellenistic and Roman Egypt (Princeton: Princeton University Press, 2001), 194.

28 Eleanor Dickey, Ancient Greek Scholarship: A Guide to Finding, Reading, and Understanding Scholia, Commentaries, Lexica, and Grammatical Treatises, from their Beginnings to the Byzantine Period (Oxford: Oxford University Press, 2007), 129-30.

29 Eugene Ulrich, "The Notion and Definition of Canon," in The Canon Debate (ed. Lee McDonald and James Sanders; Peabody, Mass.: Hendrickson, 2002), 21-35, esp. 31-32, on the evidence of the Dead Sea Scrolls, emphasizes that a book's scriptural status preceded any stabilization of form, or selection of a particular version. 
Pentateuch is from the Hellenistic period or later. Though certainly much of the divergence in form is likely to have preceded this period, it must be proven one way or the other whether Hellenistic and Graeco-Roman literary practice had an effect on the materials under examination. The premise ought not to be rejected outright.

Let us briefly review the contents of the preface before discussing why it is so valuable. In the first four verses, 2:19-22, the epitomator provides a sampling of Jason of Cyrene's history, the work which serves as his source. ${ }^{30}$ According to the epitomator, the history has several major themes: (1) Judas Maccabeus and his brothers; (2) the purification of the temple and the dedication of the altar; (3) the wars against Antiochus Epiphanes and Antiochus Eupator; (4) heavenly appearances to those who fight bravely for Judean identity; and (5) the liberation of the temple and city alongside the reestablishment of the law. Following this overview of important themes, the epitomator introduces his task. He will take the five-scroll work of Jason and attempt to shorten it into a single collection (2:23). The epitomator then provides his reasons for undertaking the work. He claims that Jason's work has too many numbers and is too difficult to delve into because of how much material is there. Instead his work is done with the intention to please the reader and be useful for those wishing to memorize the material (2:24-25). After reporting his reasons for creating the epitome, the epitomator then assures prospective readers of the effort that was spent on cutting, collecting, and crafting the new version (2:26-27). Curiously, the epitomator then moves into a description of his epitome as compared to that of Jason, wherein he employs three different illustrations of the work: (1) Jason is a compiler, responsible for exact details, while the epitomator devotes his effort to the outlines; (2) Jason is like a master builder of a new house, who must be concerned with the whole construction, while the epitomator considers only what is suitable for decoration, like one who does encaustic painting or paints decorative animals; and (3) Jason is responsible for discussing matters from all sides and troubling himself with details, while

$30 \quad$ Jonathan Goldstein, II Maccabees: A New Translation with Introduction and Commentary (Garden City, N.Y.: Doubleday, 1983), 190, argues this is not a systematic summary of either the work of the abridger or the original, but instead a collection of some of the more attractive episodes for prospective readers. This may well be, but Schwartz, 2 Maccabees, entertains the possibility that it is a summary of Jason's work on the basis of the mention of Judas's brothers, who do not feature in the shorter work we now have. This, together with the fact that v. 23 makes clear that it is the work of Jason that has just been described is decisive for me on this question. This does not rule out the possibility that this summary is incomplete, however. 
the epitomator is allowed to strive for brevity $(2: 28-31)$. The prologue then closes by providing a transition to the main text (2:32). The epitomator picks up some of the above mentioned themes again in the epilogue at 15:37-39. The first verse serves as a transition between the story and the epitomator's closing statements. He then underlines again that the purpose of his work is to present the material beautifully and succinctly in order to delight the reader. He even provides a simile in which his work is like wine mixed with water which is preferable to Jason's work, which is like unmixed wine (15:38-39). ${ }^{31}$

\section{Maccabees as Auxiliary Text}

Scholars have noted that this prefatory material uses a number of tropes employed by authors in the ancient world. ${ }^{32}$ However, it was not until recently that classical scholar, Markus Dubischar has outlined a very specific type of preface used alongside a newly discovered type of text. In his article, "Survival of the Most Condensed? Auxiliary Texts, Communications Theory, and Condensation of Knowledge," Dubischar, on the basis of the communications theory of Paul Grice, finds a category of ancient literature which Dubischar terms "auxiliary texts." ${ }^{33}$ These are texts that can be understood as aiding the reception of flawed, but otherwise valuable writings. The particular flaws any given writing has are varied, but Dubischar sees them as breaking any of four conversational maxims devised by Paul Grice: (1) Quantity: statements should be of appropriate length; (2) Quality: statements should be thorough and true; (3) Relation: statements should be relevant; (4) Manner: statements should be clear and understandable. ${ }^{34}$ Unlike personal conversation, wherein a listener

31 The practice of drinking wine mixed with water in antiquity is well catalogued. See, e.g., Hesiod, Works and Days 594-595 and Athenaeus, Deipnosophistae 10.426-427, 430431. That this custom was considered sophisticated, and therefore better than drinking unmixed wine, can be seen in Herodotus, Histories 6.84, and Plato, Laws 637e. This makes it clear that the epitomator considers his work to be more sophisticated and therefore better than Jason's.

32 Alexander, Preface, 148-51, is the most elaborate in her reading this text against GraecoRoman and Hellenistic paradigms, but Goldstein, II Maccabees, 190, also discusses elements of the preface as belonging to well-established patterns. Schwartz, 2 Maccabees, 171, agrees with previous scholars, though he does not dwell on the matter.

33 Dubischar, "Survival," 40-43. Paul Grice's communications theory into which Dubischar fits his category can be found in Paul Grice, Studies in the Way of Words (Cambridge: Harvard University Press, 1989), 27-29.

34 Dubischar, "Survival," 51-54. Grice, Studies, 26. 
and speaker can signal the flaw in a statement and force the speaker to adjust, Dubischar notices that a text, as a fixed form, is unable to do so, and because of this will inevitably fall afoul of various of the four maxims as it is transmitted through history. ${ }^{35}$ As a result, the only way to preserve a valuable text is to create a new text to "help" it, which demands a second literary hand and/or a second effort by the original hand. ${ }^{36}$

The newly created text is intended to fix the flaws of the older writing, while still preserving what is of value to its contents. Because the "flaws" in any given text are dictated by the scribes themselves, probably with some reflection on the community the scribes serve, the form any given auxiliary text takes will be varied. Indeed one text might have many auxiliaries created for it. In the Graeco-Roman material Dubischar studies, the most common types of auxiliaries are epitomes, anthologies, commentaries, and glossaries. ${ }^{37}$ In private conversation with him, I have proposed that also translations, rewritten scripture, and redactions perform the same functions and correct the same sets of flaws he sees in Graeco-Roman writings. ${ }^{38}$ If this can be demonstrated, it might prove useful for understanding the transmission of scriptural texts in our purview.

Most important in this regard, however, is that Dubischar has formulated this idea from the prefaces of Graeco-Roman auxiliary texts. That is, this idea does not belong only in the realm of theory, but can be recognized in the surviving prefaces of ancient auxiliary works. Dubischar finds two sections to most of these prefaces: (1) the "problem" section and (2) the solution section. The first of these is divided into two subsections: $\left(1^{\mathrm{a}}\right)$ establishes the importance and/or authority of the text or its contents, while $\left(1^{\mathrm{b}}\right)$ discusses the problems with the reception of the text, and by implication, the problem with the text itself. Interestingly, Dubischar finds the same pattern, whatever the subject matter, the type of auxiliary text produced, or the period from which it stems. ${ }^{39}$ It is my contention that 2 Macc 2:19-32 presents us with just such a preface. This would suggest that the epitomator sees Jason of Cyrene's work as a primary text which the epitomator is aiding for survival.

35 Dubischar, "Survival," 52-56.

36 Ibid., 56-59. The practice of self-epitomization is attested in several Graeco-Roman examples. These include such illustrious figures as Galen (De Pulsibus which is epitomized in Synopsis de pulsibus and adapted again in De pulsibus ad tirones) and Lactantius (Divinae institutiones which is epitomized in Epitoma divinarum institutionum).

37 Ibid., 41.

38 Personal communication with Markus Dubischar, July 2-3, 2014.

39 Dubischar, "Survival," 46-47. 
Let us now examine whether 2 Maccabees fits this paradigm recognized by Dubischar. In my overview above I showed that 2 Macc 2:19-22, the first four verses of the preface, were concerned with summarizing the contents, or at least highlighting some of the more interesting aspects of the book. Through the lens of the prefaces Dubischar has examined, however, we can read this section as establishing the importance of, or interest in, the contents of the original work of Jason of Cyrene. This is obviously important, because if Jason of Cyrene's text or its contents are not of interest, why would anyone want to read an epitomization of it? The praise here is not overt, but it is undeniable that it is intended as an advertisement. ${ }^{40}$ It focuses on the contents of the work, rather than the style in which it was compiled. This suggests that the epitomator might not necessarily see value in the art of Jason's work, but rather in the fantastic stories it contains. If this interpretation is correct, then, as Peter Brunt and John Yardley have noted, this would not be out of the ordinary for epitomes in the ancient world. ${ }^{41}$ This deduction can be tested with reference to the following parts of the preface.

2 Maccabees 2:23, which simply announces the intention to shorten the five volume work of Jason of Cyrene to one scroll is probably best understood as the beginning of the notice of problems in Jason's work, though it may actually be an early reference to correcting the problems with Jason's history. In any case, the announcement already hints at one of the problems with Jason's history; it is far too long to be useful. It is five books long and the new work only occupies one fifth the space. But the epitome itself is already of standard length for writings of the time. ${ }^{42}$ The criticism of length is not only inherent in the type of auxiliary text created, i.e., an epitome, but made explicit in verses 24 and 25, where the epitomator complains of difficulty on account of

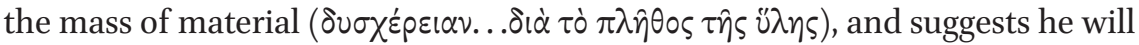

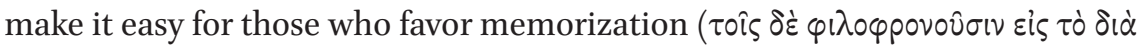
$\left.\mu \nu \eta \dot{\mu} \eta \operatorname{\alpha }^{\alpha} \nu \alpha \lambda \alpha \beta \varepsilon i v \varepsilon \dot{x} x \circ \pi i \alpha \nu\right)$. So, it would seem rather clear that one of the problems is the sheer size of Jason's work. This breaks the Gricean conversational

40 So Goldstein, II Maccabees, 190.

41 Peter Brunt, "On Historical Fragments and Epitomes," CQ 30 (1980): 477-94, esp. 487. See also the statement of John Yardley, "What is Justin Doing with Trogus?" in Horster and Reitz, Condensing, 469-9o, esp. 475-76.

Schwartz, 2 Maccabees, 175-76, calculates the length using the methodology (35 letters/ manuscript line) and tables provided by Theodor Birt, Das antike Buchwesen in seinem Verhältniss zur Literatur (Berlin: Hertz, 1882), 310-14 as being a medium-sized volume at 1694 lines. 
maxim of quantity pointed out above. Some audiences prefer not to read or hear texts that can be communicated more briefly.

Another problem pointed out in verse 24 is the mass of numbers that apparently fill Jason's work ( $\tau \dot{\partial} \chi \dot{\nu} \mu \alpha \tau \hat{\omega} \nu \dot{\alpha} p(\theta \mu \hat{\omega} \nu)$, which Schwartz suggests probably refers to distances, sizes of armies, etc. ${ }^{43}$ This would seem to violate Grice's fourth maxim of manner. The frequent use of numbers makes the text harder to understand. However, it should be noted that other scholars, such as Elias Bickerman, Jonathan Goldstein, and Robert Doran, interpret this statement as another reference to the size of book, i.e., number of standard lines. ${ }^{44}$ Either possibility is plausible. Even later indications of brevity of style and less attention to detail being a feature of the epitomator's work are not decisive, because if the scribe did not appreciate the frequent use of numbers, he still included quite a few. ${ }^{45}$ Whether there is only one problem (quantity) expressed in three different ways or two problems (quantity and manner), the epitomator is here noting the troubles with the text which lead to difficulties for those who want to dive into the history. In any case, it is possible that both the length and detail of Jason's work are understood as problematic for the epitomator and the epitomator's intended audience. This is clarified by the following verse in which he states his goals in (1) making the epitome amusing for those who wish to read; (2) making it easy for those who favor memorization; and (3) benefitting anyone who happens upon the text. These basically reinforce the impression that the text is too long, too cumbersome to memorize, and possibly too filled with detail.

Dubischar's second part of the preface, in which the auxiliary scribes explain how they will attain their goals, does not appear immediately. Instead, there are two formulaic verses about the toil and suffering involved in producing the text. Although these types of statements are common in prefaces of all types (e.g., Sirach prologue 30-35; Ant. 1.7-9), ${ }^{46}$ they are not an integral part of

43 Schwartz, 2 Maccabees, 176. The NETs translation of 2 Maccabees would seem to agree.

44 Elias Bickerman, Studies in Jewish and Christian History: A New Edition in English Including The God of the Maccabees (ed. Amram Tropper; 2 vols.; Leiden: Brill, 2007), 1:248 n. 36, originates the argument, but Goldstein, II Maccabees, 192, makes a related argument that a "number" was a standard unit of writing measuring sixteen syllables, referring again back to the length. Robert Doran, Temple Propaganda: The Purpose and Character of 2 Maccabees (Washington, D.c.: Catholic Biblical Association of America, 1981), 77-78, also agrees.

45 Bezalel Bar Kochva, Judas Maccabeus: The Jewish Struggle against the Seleucids (Cambridge: Cambridge University Press, 1989), 178 n. 82, counts more than fifty numbers, which Bar Kochva takes to mean that Jason's work must have been full of them.

46 Alexander, Preface, 150 , notes the commonness of this trope. 
prefaces to auxiliary texts. After this brief interruption, at verse 28 we come to the explanation of how the epitomator will solve the problems in Jason's text. First, he says he will concede the precise details to Jason, and will himself work out the outlines of the epitome. Thus, even if both manner and quantity are the problems, they have the same solution: skip the details, thereby producing a shortened, more superficial version. The slightly confusing simile concerning the master builder and painter that follows is clarified by the succeeding verse. Though one would expect that the painter is concerned with details, while the master builder is concerned with the general outline, the epitomator explains that his role is artistic and stylistic as opposed to the more thorough and fundamental place of Jason. As a result he will accomplish his goals by being brief and removing complex details. This explanation may seem to be less than flattering to the epitomator's work. But one must consider that the scribe and possibly his audience seem to have preferred a text of this type, which mixes a better style with less substance. This is again made explicit in the epilogue wherein the epitomator's chief concern is that the book was well written and to the point, like the Hellenic (and therefore sophisticated) mixed wine as opposed to the barbaric (but more substantial) pure wine.

As a result of reading this text in light of Dubischar's special category of auxiliary text prefaces, we can begin to draw some conclusions. The epitomist seems to have, like other creators of auxiliary texts, seen his new variant as an improvement upon the primary text of Jason. ${ }^{47}$ We can assure ourselves of this because of the criticisms lobbed at Jason's work and the comparison of the epitomator's own work to the highly civilized mixed wine. The improvements the epitomist has made are in the realm of manner-it is devoid of detailsand quantity - it is relatively brief. These changes allow for it to be read and memorized more easily, thereby pleasing at least a segment of the potential audience. These types of improvements are typical of other auxiliary texts with prefaces. ${ }^{48}$ This would seem to prove that not only does such a concept exist in the mind of an ancient scribe, but in a Judean scribe. ${ }^{49}$ Might this suggest that such adaptation to texts and traditions was not only recognized by audiences but even valued? Though many other Judean texts cannot be tested in such a way because they lack prefatory materials, should we not consider that they, too might be conceived of in this primary/auxiliary relationship? It may

47 Markus Mülke, “Die Epitome-Das bessere Original?” in Horster and Reitz, Condensing, 69-89, esp. 74-76. Yardley, "What is Justin," 472.

48 Dubischar, "Survival," 47-48.

49 The Judean character of our scribe can be recognized in his interest in the temple and his terming of the Seleucid armies as barbarians. 
well be that texts such as Jubilees or $4 \mathrm{Q}_{15} 8$ are correcting traditions or textual variants that their authors understand to be valuable, but flawed.

\section{Maccabees in its Hellenistic and Judean Context}

There are several possible objections to importing our findings from 2 Maccabees into other Judean texts. First, 2 Maccabees expressly makes claim to the genre and strategy of epitomization; other Judean texts make no such claim. It is true that 2 Maccabees claims to be an epitome, but it is highly debatable whether shortening the text is the only activity undertaken by the author. As John Yardley has pointed out, epitomists in general are not simply excerptors, but often create autonomous works. ${ }^{50}$ Further, though it is popular since Goldstein, to call the scribe responsible for 2 Maccabees an epitomator, Gary Morrison, Daniel Schwartz, and Victor Parker have all recently asserted the authorial function for the scribe and claim a great role for him in shaping the current text. ${ }^{51}$ Unfortunately these claims cannot be tested, both because we lack the work of Jason of Cyrene, and because it is evident from the prefixed letters and 10:1-8, that 2 Maccabees as it stands now is not the work produced by the epitomator. ${ }^{52}$ However, it remains a significant possibility, given the historical and literary context, that the epitomator was just as active, and used some of the same techniques, as the scribes who created the variants for which we have empirical evidence. Because of this, we should not let the specific form of auxiliary text prevent us from recognizing other Judean texts in this primary/ auxiliary paradigm. In such a case we could hypothesize whether Chronicles is an auxiliary to the text of Samuel-Kings, or even whether Deuteronomy is an auxiliary to Exodus. Though these theories would have to be tested by careful

5o Yardley, "What is Justin," 473.

51 Goldstein, II Maccabees, 5, claims that the narrative reads "like a chain of isolated incidents." However, Daniel Schwartz, 2 Maccabees, 37, asserts that the epitomator should be called an author because he not only made Jason's work more readable but added other material, including a preface, an epilogue, chapter 3 , and several other sections of comment. Victor Parker, "The Letters in II Maccabees: Reflexions on the Book's Composition," ZAW 119 (2007): 386-402, esp. 401, suggests it because the epitomator reworked and added portions of material in chapter 11 and perhaps chapter 9, as well. Gary Morrison, "The Composition of II Maccabees: Insights Provided by a Literary topos," Biblica 90 (2009): 564-72, esp. 571-72, claims that the epitomator is an historian in his own right for having written chapters 3 and 4 , and sections of chapters 5, 9, and 14.

52 David Williams, "Recent Research in 2 Maccabees," in CBR 2 (2003): 69-83, esp. 72-73. 
comparison, the existence of 2 Maccabees and its prologue shows that such transmission was possible within the Judean literary milieu.

A second objection might be that 2 Maccabees is a Hellenistic text written in Greek, abridging a text written in the Greek-speaking Diaspora where there may have been an entirely foreign text and authorial culture. ${ }^{53}$ Such a caution should be taken seriously, but we must be careful not to give it more than its due. Though, as is plainly evident, the author of the primary text is named, our epitomator remains anonymous. Further, neither the work the epitomator produced nor Jason's primary history appear to have been recognizable by a title, otherwise our epitomator would have used it. Instead the text is recognizable by its contents. It is true that the fact that there is a preface of any sort does indicate some participation in Hellenistic or Graeco-Roman book culture. ${ }^{54}$ However, not all Graeco-Roman texts have prefaces while several Judean texts do. This brings the text tradition of 2 Maccabees into the same realm as other Judean texts, like the book of Sirach, the Letter of Aristeas, the works of Josephus, and Luke-Acts. That this particular text is Hellenistic and may follow Hellenistic literary convention should also not be seen as problematic. Let us not forget that all of our earliest empirical evidence for scriptural transmission also comes from the Hellenistic milieu. ${ }^{55}$ This means we cannot dismiss 2 Maccabees simply because it comes from the same period of time. It may well be that the scribes transmitting texts found in the Judean desert or working on the Old Greek translations and their transmission had similar concepts running through their minds.

\section{Conclusion}

Allow me to close by noting that we should take seriously the possibility that many (though not all) scribes adapting texts in this ancient milieu did so with similar presuppositions. They wanted to preserve traditions, but recognized

53 Van der Toorn, Scribal, 39, for example remarks that Ben Sira is among the first authors and produces one of the first works that resembles books.

54 See, e.g., Lucian of Samosata, How to Write a History, 53, wherein the form and function prefaces of histories are described as part of the proper way to compose a history.

55 Robert Carroll, "Jewgreek Greekjew: The Hebrew Bible is All Greek to Me: Reflections on the Problematics of Dating the Origins of the Bible in Relation to Contemporary Discussions of Biblical Historiography," in Did Moses Speak Attic? Jewish Historiography and Scripture in the Hellenistic Period (ed. Lester Grabbe; Sheffield: Sheffield Academic, 2001), 91-107, esp. 93. 
the limitations of those traditions within specific contexts, whether on account of their failure to communicate clearly, or their lack of relevance, or their conformity with ideology, or simply their length. So, they needed to be corrected. This should change the common question many of us ask when dealing with texts existing in some sort of relationship: "Was text B meant to replace text A?" This common question would seem to be insufficiently formulated, if 2 Maccabees and texts like it can be taken as a paradigm. The answer to such a question would by necessity be complex. The author of 2 Maccabees intended to replace Jason's work, but only explicitly for those interested in memorizing the text and those who might have difficulty reading. For others, engaged in in-depth study, the epitomator probably agreed that Jason's work could not be ignored. This much is clear from the constant reference back to Jason's function as one who provides exact details. The epitomator's own work in such a case could likely either be ignored, or more likely used as an aide-memoire for Jason's work. As a result of this study, we might find a better way to formulate the common question just cited: "For whom was text B meant to replace text A?" Though the question may be far harder to answer in many cases, it at least asks a question that was demonstrably of interest to ancient Judeans. 